\title{
Integration of Islamic Values in Elementary School
}

\author{
Nurdyansyah Nurdyansyah \\ Fakultas Agama Islam \\ Universitas Muhammadiyah Sidoarjo \\ Sidoarjo, Indonesia \\ nurdyansyah@umsida.ac.id
}

\author{
Moch. Bahak Udin By Arifin \\ Fakultas Agama Islam \\ Universitas Muhammadiyah Sidoarjo \\ Sidoarjo, Indonesia \\ bahak.udin@umsida.ac.id
}

\begin{abstract}
- the ideal education should to develop (tarbiyah) potential (fitrah) students become precious human. During this time the reality of Islamic education trapped in problem of secularization dichotomy and sacralization education. Religion is define as something that take care of worship which set aside of science and technology. The aim of development integration Islamic value in social science at elementary school is to produce a new text book which give a comprehension to the students that the general science and religion is holistic. It is using Brog and Gall model to determine the success of product development of integration Islamic value of social science in elementary school. It is measured by validity level and effectiveness. The validity level is measured by the result of expert validation and the effectiveness measured by response of the students, process of learning and students learning complete in classical. The result shows the implementation of integration Islamic value and social value able to improve the students understanding, on the other hand, we can get the same result if we apply to the students or school that does not has good understanding of Islam,
\end{abstract}

Keywords - Integration of Islamic values; social science; elementary school

\section{INTRODUCTION}

Educational process is the process of developing student's potential until they become the heirs and the developer of nation's culture. The education should to give a foundation with all the aspect that needs for sustainability nation's life to reflect their personality.

Education has function to developing ability and creates a personality also civilization of a dignified nation in educate the nation's life. The purpose to develop students' potential become faithful and cautious to the God, has a good attitude, healthy, knowledgeable, capable, creative, independent, and become a democratic and responsible citizen [1]. Depend on the function and the purpose of the national educations, then, the development of curriculum based on the nation's culture, nowadays nation's life and nation's life in the future[2].

Education of elementary school has complex problem. One of the problems is globalization [3] in ethics culture moral, as the impact of technology progress in information. The advance development of media that makes the teacher especially Islamic education's teacher has move [4], especially in educate the student's morality. Nowadays, the students know the massage of source of the lessons which pedagogic and easy to control, there are many more that does not able to controlled.
The ideal education should to develop the students' potential which appropriate with sense of the education itself, that is improve and develop (tarbiyah) potential (fitrah) human become a precious human. The reality of Islamic education world [5] trapped in the problem of secularization dichotomy [6] and sacralization of education [7]. Secularization's meaning is education has separated itself from the Islamic religion. Islamic religion is define as something that take care of worship which set aside of science and technology.

Social science educate how human's interaction to the environment [8], become a keys of reflection of attitude and behavior in social life. Look up the reality of the complex education's problem, it is naturally to make an innovation of integration Islamic value in social science. Because, score [9], [10] cannot measure the bad and good of someone's attitude in their social life. The integration of Islamic value has purpose to give an understanding for the students that social science and Islamic science are holistic, so, it can handle of the moral problem that happened [11].

\section{METHOD}

Research of this integration of the Islamic value used research and development (R\&D) Brog \& Gall model [12], which modify until ninth steps, as for the steps performed as follows: (1) research and information collecting, (2) planning, (3) develop preliminary form of product, (4) preliminary field testing, (5) main product revision, (6) main field testing, (7) operational product revision, (8) operational field testing, (9) final revision product. It can be seen in picture 2 . To know the level of integration Islamic value effectiveness, it used questionnaires with 5 scoring scale that is VA (very appropriate) is worth 5, A (appropriate) is worth 4, QA (quite appropriate) is worth 3, LA (less appropriate) is worth 2, NA (not appropriate) is worth 1 , and then analyze by statistical analysis using formula in figure 1.

$$
\mathrm{P}=\frac{\sum \mathrm{X}}{\sum \mathrm{X}_{\mathrm{i}}} \times 100 \%
$$

Fig. 1 Data analysis formula

Explanation:

$\begin{array}{ll}\mathrm{P} & : \text { is the properness percentage } \\ \Sigma \mathrm{X} \Sigma \mathrm{X} & : \text { Sum of answer total score (real score) } \\ \Sigma \mathrm{X}_{\mathrm{i}} \sum \mathrm{X}_{\mathrm{i}} & : \text { Sum of highest total score (prospect score) }\end{array}$




\section{RESULT AND DISCUSSION}

The needs of analysis study that elementary school did has already prepared a leaning media. One of the learning media is textbooks that contain of integration Islamic value. From the test result of preliminary field testing shows accomplishment until $90 \%$ percentage. The textbook which is integrating social science to Islamic value has a good qualification, and the suggestion from respondent used to revise the initial product. The result of the initial product will describe the integration of Islamic value in the social science textbook, indirectly, support the view which explains religion (al-dîn) and knowledge (al-'ilm) that see as different knowledge (dichotomy), which placed separate religion and knowledge [13]. Islam ideologically believed to be universal, but in practice it position as marginal and less contribute which significance in the developing civilization and education in Indonesia.

In the main field testing part, found a percentage rate of students' understanding of content of the textbook is $91,99 \%$, it has a good coalification. It is shows the fast improvement of technology and science. The values of Islamic are relevant and easy to understand [14].

The integration of Islamic value is very helpful because it has found the new format about integration of religion (define knowledge) and science (scientific knowledge) which the truth is absolute, because it comes from the God [15], while the other that is science which scientific findings of relative truth [16], it is the result of the human research and the power of reason that can be re-verified at any time.

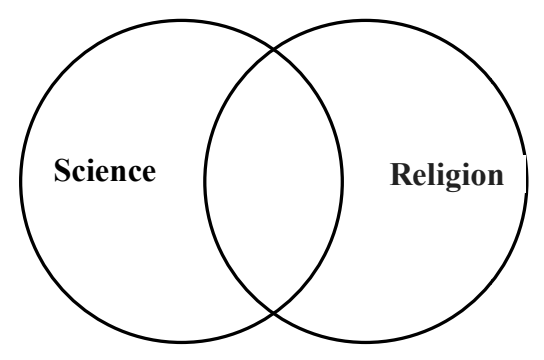

Fig. 2 Dyadic Dialogic Models

Operational field testing has gain $87,05 \%$ percentage, it placed in the coalification of good understanding. Next, the suggestion of the respondent becomes a final repair of this material. From the tree testing it can conclude that integration of Islamic value help the students easy to understand social science. In this part, the social science which is meant by the researcher is the subject that discuss about life aspects of society by using concepts that exist in the social science. Changes that occur in society are the result of social integration. Positive or negative in the society it know from the context of time and place. Furthermore, it is become material of social science. The wide context will make a globalization. The correlation between individual and group in the globalization will create competitive relationship. In this case, it will create interplay relationship. Value of the system of every individual and group has impact of in that pattern. The things that should to avoid from this pattern is the existence of exploitative relation and group hegemony that is contrary to the principles of humanity and justice. In addition, it also be avoided the existence of the revocation of values that owned by a society that impact on the loss of identity of the community. In response to these changes the development of social science materials based on kebinekaan, local wisdom, and divinity, reflecting the identity of the unity on Indonesia.

The integration of Islamic-Scientific Values as "we do not drink a glass of $\mathrm{H} 20$, but a glass of water" integrates Islamic values using dyadic models [17], [18], [19], which describe Islam and science as an inseparable unity. "Science does not need mysticism and mysticism does not need science, but humans need both. While the third variant argues that between science and religion have similarities. This equation used as material integration of both. This third variant can be illustrated by a two-circle diagram equally intersecting. Both circles reflect Islam and science, so there is something in common. It can be seen in figure 2 .

\section{CONCLUSION}

The result of the integration of the Islamic value in social science at the preliminary field testing shows the percentage $90 \%$ accomplishment in good coalification, in the main field testing found the level percentage of students understanding of material contain in social science which integrate with Islamic value book is $91,66 \%$ in very good qualification, and the operational field testing gain $87,05 \%$ which shows the students understanding in the learning process at teaching learning of social science which integrated with Islamic value include in good category. The result of this research support a theory that state Islam is universal, and values in Islamic religion is the social value that grow in society.

Suggestion and recommendation to developing integration of Islamic value with natural science, are able continue to develop with integration of strategy or model of general learning, in order to moral values in Islam able to implement become students competent without learning particular of religion itself.

\section{ACKNOWLEDGMENT}

This research and development supported by Faculty of Islamic Studies Universitas Muhammadiyah Sidarjo, research institutes and community service of Universitas Muhammadiyah Sidoarjo and Muhammadiyah 2 elementary school Sidoarjo.

\section{REFERENCES}

[1] Departemen Pendidikan Nasional Badan Penelitian Dan Pengembangan, "Naskah Akademik Kajian Kebijakan Kurikulum Mata Pelajaran Ilmu Pengetahuan Sosial (IPS)," Pusat Kurikulum, Jakarta, 2007. (References)

[2] Daniel Tanner and Laurel Tanner, "Curriculum Development: Theory Into Practice," Publisher: Pearson, Copyright 4, 2006.

[3] N Marlow, A S Rose, C E Rands, E S Draper, "Neuropsychological and educational problems at school age associated with neonatal encephalopathy," Arch Dis Child Fetal Neonatal Ed, Vol. 90, 2005, pp.384-386.

[4] Matthias Kohring and Jorg Matthes, "Trust News Media: Development and Validation of a Multidimensional Scale," Communication Research, Vol 34, No 2, April 2007, pp.231-252. 
[5] Dale F. Eickelman, "The Art of Memory: Islamic Education and its Social Reproduction," Vol 20, Issue 4, October 1978, pp. 485-516.

[6] Karel Dobbelaere, "Secularization Theories and Sociological Paradigms: A Reformulation of the Private-Public Dichotomy and the Problem of Societal Integration," Sociology of Religion, Vol 46, Issue 4, 1 December 1985, pp. 377-387.

[7] Asma Jana-Masri \& Paul E. Priester, "The Development and Validation of a Qur'an-Based Instrument to Assess Islamic Religiosity: The Religiosity of Islam Scale," Journal of Muslim Mental Health, Vol 2, Issue 2, October 2007, pp. 177-188.

[8] Stephen P. Borgatti, Ajay Mehra, Daniel J. Brass, Giuseppe Labianca, "Network Analysis in the Social Sciences," Vol. 323, Issue 5916, February 2009, pp.892-895.

[9] Lukman Hakim, "Internalisasi Nilai-Nilai Agama Islam Dalam Pembentukan Sikap dan Perilaku Siswa Sekolah Dasar Islam Terpadu Al-Muttaqin Kota Tasikmalaya," Jurnal Pendidikan Agama IslamTa'lim, Vol. 10, No. 1, 2012, pp. 67-77.

[10] Carolyn Ball, Akhlaque Haque, "Diversity in Religious Practice: Implications of Islamic Values in the Public Workplace," Vol. 32, No. 3, 2003, pp. 315-330.

[11] Valentine M. Moghadam, "Islam Integration and the Feminits Alternative,” Bobst Library: New York University, June 2015, pp. 516519.

[12] Walter Borg dan Meridith D. Gall, "Educational Research an Introduction (Fourth Edition)," New York: Longman, 1983.
[13] J. Wentzel van Huyssteen, "The Shaping of Rationality: Toward Interdisciplinarity in Theology and Science," Michigan: WilliamB Eerdmans Publishing Company, 1999.

[14] Moneef Rafe' Zou'bi, "Science Education in the Islamic World: A Snapshot of the Role of Academies of Sciences," Procedia-social and Behavioural Sciences, Vol. 192, June 2015, pp. 359-363.

[15] Kamarudin Zaelani, "Philosophy of Science Actualization for Islamic Science Development: Philosophical Study on an Epistemological Framework for Islamic Sciences," Pacific Science Review B: Humanities and Social Sciences, Vol. 1. Issue, November 2015, pp.109113.

[16] Daniel Steel, Chad Gonnerman, Michael O'Rourke, Scientists' attitudes on science and values: Case studies and survey methods in philosophy of science, Vol. 63, June 2017, pp. 22-30.

[17] Stephen E. Humphrey, "Federico Aime, Lily Cushenbery, Aaron D. Hill, Joshua Fairchild, Team conflict dynamics: Implications of a dyadic view of conflict for team performance," Vol. 142, September 2017, pp. 5870.

[18] Mariana A. Preciado, Jennifer L. Krull, Andrew Hicks, Jessica D. Gipson, "Using a dyadic logistic multilevel model to analyze couple data," Vol. 93, Issue 2, February 2016, pp. 113-118.

[19] Katherine J.W. Baucom, Brian R. Baucom, Andrew Christensen, "Changes in dyadic communication during and after integrative and traditional behavioral couple therapy," Vol. 65, February 2015, pp. 1828. 